\section{ПЕРСПЕКТИВИ \\ РОЗВИТКУ \\ ЗОВНІШНЬОЕКОНО- \\ МІЧНОЇ ДІЯЛЬНОСТІ ПІДПРИЕМСТВ АПК ${ }^{10}$}

\author{
БРОЯКА А. А., \\ кандидат економічних наук, доцент, \\ доцент кафедри економіки, \\ Вінницький національний \\ аграрний університет
} (м. Вінниця)

У статті досліджено сутність зовнішньоекономічної діяльності підприємств, особливості та перспективи ї здійснення у сфері АПК. На основі проведеного аналізу, доведено, щзо аграрний експорт України відіграє вагому роль у формуванні бюджету та ВВП крайни, адже його частка у 2018 рочи становила 14,2\% ВВП та 33, 4\% загального вітчизняного експорту товарів. Здійснено аналіз динаміки експортно-імпортних операцій аграрного сектору та виявлено, щзо він демонструє позитивну тенденцію на відміну від загального зовнішньоторговельного сальдо України. Аналіз структури аграрного експорту у 2010-2019 роках підтверджує зростання частки більшості видів аграрної продукиї̈, спрямованої за межі краӥни. Проте, украӥнський експорт має переважно сировинну спрямованість, яка, серед інших причин, пов'язана з технологічною відсталістю й обмеженими можливостями вітчизняних агровиробників щцодо закупівлі сучасного обладнання та устаткування внаслідок низької платоспроможності. Сировинна орієнтація украйнського експорту робить конкурентні позиції України на зовнішніх ринках вразливими, оскільки попит на сировинні товари є нестійким і характеризується значною ичіновою мінливістю.

Досліджено географічну структуру зовнішньої торгівлі аграрною продукцією та можливості ї̈ подальшої диверсифікації. Найбільще украӥнської продукиії в Свропі купують у Польщі, Італії, Німеччині. Значними почіновувачами украӥнської продукцї $\epsilon$ також Туреччина, Китай, Індія, Сгипет. Український експорт варто розширювати у країни Азї та Cxодy.

Виявлено ключові проблеми, щь гальмують розвиток зовнішньоекономічної діяльності підприємств АПК та перешкоджають зміцненню конкурентоспроможності вітчизняної аграрної продукиї на міжнародному ринку. Запропоновано ряд заходів щчо сприятимуть подальшому розвитку зовнішньоекономічної діяльності підприємств АПК, серед яких розробка відповідних стратегій з урахуванням світових ринкових тенденцій, гармонізація та дотримання стандартів якості та безпечності аграрної продукиії, удосконалення інноваційної складової, посилення державної підтримки (у т.ч. фінансової) екпортноорієнтованих аграрних підприємств, покращення інвестиційного клімату тощо.

Ключові слова: зовнішньоекономічна діяльність, зовнішня торгівля, експорт, імпорт, АПК, аграрна продукція.

Табл. 2. Рис. 2. Літ. 13.

\title{
PROSPECTS FOR THE DEVELOPMENT OF FOREIGN ECONOMIC ACTIVITY OF THE ENTERPRISES OF AGRARIAN AND INDUSTRIAL COMPLEX
}

${ }^{10}$ БРОЯКА А.А., 2020 


\title{
BROYAKA Antonina, Candidate of Economic Sciences, Associate Professor of Economics Department, Vinnytsia National Agrarian University
}

(Vinnytsia)

The article examines the essence of foreign economic activity of enterprises, the features and prospects of its implementation in the field of agrarian and industrial complex. Based on the conducted analysis, it is proved that agrarian export of Ukraine plays a significant role in the formation of the budget and GDP of the country, since its share in 2018 was $14.2 \%$ of GDP and $33.4 \%$ of the total national exports of goods. The dynamics of export-import operations of the agrarian sector is explored and it is found that it demonstrates a positive trend in contrast to the general foreign trade balance of Ukraine. The analysis of the agrarian exports structure in 20102019 confirms the growth of the share of the majority of agrarian products types sold abroad.

However, Ukrainian exports are mainly oriented towards raw materials, which, among other reasons, is associated with technological backwardness and the limited ability of domestic agricultural producers to purchase modern equipment and technologies due to theirs low solvency. The commodity orientation of Ukrainian exports makes the competitive position of Ukraine in foreign markets vulnerable, since the demand for commodities is unstable and is characterized by significant $\$$ price volatility.

The geographical structure of foreign trade in agrarian products and the possibilities of its further diversification are investigated. The majority of Ukrainian products in Europe are purchased in Poland, Italy and Germany. Significant connoisseurs of Ukrainian products are also Turkey, China, India, Egypt. Ukrainian exports should be expanded to Asian and Eastern countries.

The key problems that put the brakes on the development of the foreign economic activity of the enterprises of agrarian and industrial complex and hinder the competitiveness increase of domestic agrarian products in the international market are identified. A number of measures are proposed to promote the further development of the foreign economic activity of the enterprises of $\dot{\Xi}$ agrarian and industrial complex, including the development of appropriate strategies taking into account global market trends, harmonization and compliance with the quality and safety standards of agrarian products, improving the innovative component, strengthening state support (including financial) of the export-oriented agrarian enterprises, improving the investment climate, and more.

Keywords: foreign economic activity, foreign trade, export, import, agrarian and industrial complex, agrarian products.

Tabl.: 2. Fig.: 2. Lit.: 13.

\section{ПЕРСПЕКТИВЫ РАЗВИТИЯ ВНЕШНЕЭКОНОМИЧЕСКОЙ ДЕЯТЕЛЬНОСТИ ПРЕДПРИЯТИЙ АПК}

\author{
БРОЯКА А. А., \\ кандидат экономических наук, доцент, \\ доцент кафедры экономики, \\ Винницкий национальный аграрный университет:
} (2. Винница)

В статье исследована сущность внешнеэкономической деятельности предприятий, особенности и перспективы ее осуществления в сфере АПК. На основе проведенного анализа, 
доказано, что аграрный экспорт Украины играет важную роль в формировании бюджета и ВВП страны, поскольку его доля в 2018 году составляла 14,2\% от ВВП и 33,4\% от общего отечественного экспорта. Осуществлен анализ динамики экспортно-импортных операџий аграрного сектора и обнаружено, что он демонстрирует положительную тенденцию в отличие от общего внешнеторгового сальдо Украины. Анализ структурь аграрного экспорта в 2010-2019 годах подтверждает рост доли большинства видов аграрной продукиии, направленной за предель страны. Однако, украинский экспорт имеет преимущественно сырьевую направленность, которая, среди прочих причин, связана с технологической отсталостью $u$ ограниченными возможностями отечественных агропроизводителей относительно закупки современного оборудования и технологий вследствие низкой платежеспособности. Сырьевая ориентаџия украинского экспорта делает конкурентные позищии Украины на внешних рынках уязвимыми, поскольку спрос на сырьевые товары является неустойчивым и характеризуется значительной ценовой изменчивостью.

Исследовано географическую структуру внешней торговли аграрной продукцией и возможности ее дальнейшей диверсификаџии. Наибольшее количество украинской продукции в Европе покупают в Польше, Италии, Германии. Значительными ценителями украинской продукиии являются также Туриия, Китай, Индия, Египет. Украинский экспорт стоит расширять в страны Азии и Востока.

Выявлены ключевые проблемы, тормозящие развитие внешнеэкономической деятельности предприятий АПК и препятствующче укреплению конкурентоспособности отечественной аграрной продукиии на международном рынке. Предложено ряд мероприятий, которые будут способствовать дальнейшему развитию внешнеэкономической деятельности предприятий АПК, среди которых: разработка соответствуюших стратегий с учетом мировых рыночных тенденций, гармонизация и соблюдение стандартов качества и безопасности аграрной продукиии, совершенствование инновационной составляющей, усиление государственной поддержки (в т.ч. финансовой) екпортноориентированных аграрных предприятий, улучшение инвестиционного климата и тому подобное.

Ключевые слова: внешнеэкономическая деятельность, внешняя торговля, экспорт, импорт, АПК, аграрная продукция.

Табл. 2. Рис. 2. Лит. 13.

Постановка проблеми. Зовнішньоекономічна діяльність у сучасних умовах глобалізації та євроінтеграції відіграє важливу роль у розвитку економіки держави та іiї суб'єктів господарювання. В Україні на тлі останніх політичних та економічних змін відбувається переформування структури взаємного товарообміну із світовою спільнотою, оновлення економічної політики як внутрішніх, так i зовнішніх сфер, пов'язаних з удосконаленням механізму управління зовнішньоекономічною діяльністю. Зважаючи на визначальне місце галузей АПК в економіці України та формуванні іï продовольчої безпеки й враховуючи експортний потенціал цієї сфери у контексті сучасної економічної політики, особливої уваги набувають питання активізації зовнішньоекономічної діяльності підприємств, що займаються виробництвом та переробкою сільськогосподарської продукції. Здійснення ефективної зовнішньоекономічної діяльності вітчизняними аграрними підприємствами сприятиме підвищенню їхньої конкурентоспроможності на світових ринках, формуванню раціональної структури експорту й імпорту, а також залученню іноземних інвестицій в 
аграрну сферу країни на взаємовигідних умовах.

Аналіз останніх досліджень та публікацій. Дослідження зовнішньоекономічної діяльності вітчизняних підприємств АПК знайшли своє відображення в наукових працях І.В. Безп'ятої [1], Л.М. Березіної, О.С. Головочавої, С.М. Кваші, А.І. Кредісова, Г.В. Марків, А.А. Мазаракі, Б.Й. Пасхавера, Е.В. Пахучої [6], Н.Я. Пітель [7], І.В. Пономаренко, А.М. Прощаликіної [8], А.М. Сиротюк [9], Ставської Ю.В. [10, 11], Хаєцької О.П. $[12,13]$, T.M. Циганкової та інших. Незважаючи на значну кількість напрацювань у цій сфері, питання визначення перспективних напрямів та чинників розвитку зовнішньоекономічної діяльності підприємств АПК завжди залишається актуальним у зв'язку із невизначеністю та нестабільністю економічного середовища, в якому вони функціонують.

Формулювання цілей статті. Головною метою дослідження є оцінка умов та особливостей здійснення зовнішньоекономічної діяльності підприємствами агропромислового комплексу України як підгрунтя для визначення шляхів іiі подальшого розвитку та розробки рекомендацій щодо ії удосконалення.

Виклад основного матеріалу дослідження. Зовнішньоекономічна: діяльність $є$ однією 3 найбільш важливих та невід'ємних сфер економічної діяльності, під якою ми розуміємо сукупність виробничо-господарських, організаційно-економічних і комерційних функцій підприємств, пов'язаних зі співпрацею 3 іноземними партнерами. Згідно 3 економічним словником, зовнішньоекономічна діяльність - це сфера економічної діяльності держави і підприємств, яка тісно пов'язана із зовнішньою торгівлею, експортом та імпортом товарів, іноземними кредитами та інвестиціями, реалізацією спільних з іншими країнами проєктів [4, с. 44]. Успішне здійснення зовнішньоекономічної ё діяльності посилює інтеграцію держави у міжнародний ринок, що в подальшому сприяє покращенню рівня добробуту й розвитку суспільства та розширенню зони впливу національної економіки загалом у світі.

Зовнішньоекономічна діяльність виконується в основному на рівні підприємства як головної господарчої ланки економічної системи. Отже, зовнішньоекономічну діяльність підприємства можна визначити як сукупність заходів, які здійснюються підприємством на зовнішньому ринку, зокрема: торгівлі, надання послуг, спільного підприємництва, участі в інтеграційних та глобалізаційних процесах тощо для досягнення ефективного використання переваг міжнародного поділу праці. Зовнішньоекономічна діяльність підприємства, яка здійснюється шляхом реалізації зовнішньоекономічних зв'язків, розглядається як невід'ємна сфера господарської діяльності, здатна позитивно впливати на ефективність виробництва, його технічний рівень, якість виробленої продукції.

Аграрне виробництво $\epsilon$ провідною бюджетоутворювальною галуззю економіки України, яка не тільки задовольняє продовольчі потреби населення, а й $є$ основою зовнішньої торгівлі України та важливим джерелом валютних надходжень у країну [2]. Згідно з даними Державної служби статистики України, 
аграрний експорт країни у 2018 році становив 18611,8 млн дол. США, при цьому частка експортованої аграрної продукції у структурі ВВП України становила $14,2 \%$, що у 2 рази більше, ніж у 2010 році (рис. 1). Аналізуючи динаміку 20102018 років, бачимо, що частка загального експорту товарів у складі ВВП незначно коливається, тоді як роль експорту аграрної продукції в економіці країни підвищується.

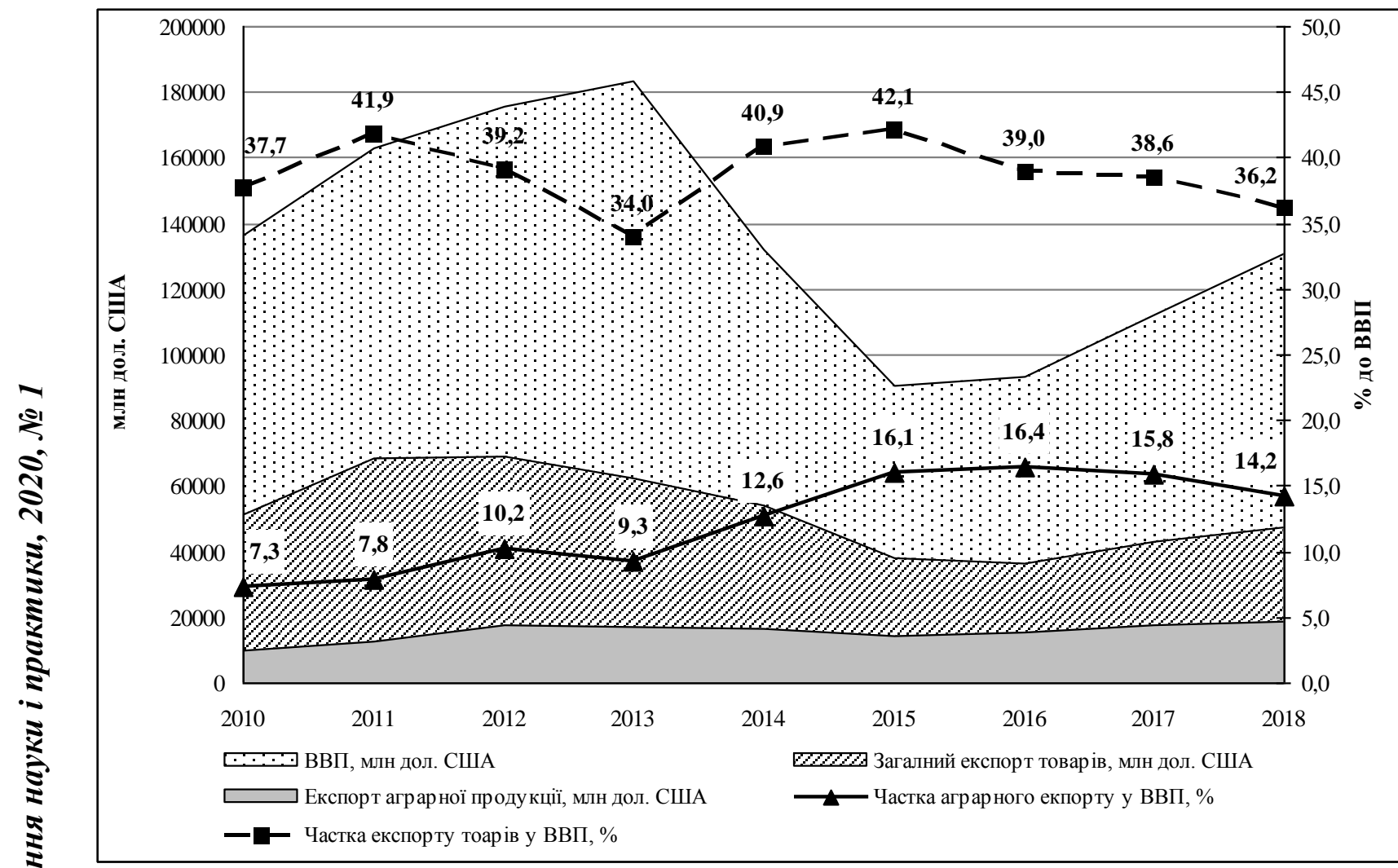

Рис. 1. Динаміка ВВП України та частки експорту у його структурі у 20102018 роках

Джерело: сформовано автором на основі даних Державної служби статистики Украӥни [5]

Протягом останніх років саме сільське господарство перманентно показує найбільше позитивне сальдо в зовнішній торгівлі товарами. Причому, воно стабільно зростає, тоді як загальне зовнішньоторговельне сальдо має негативну тенденцію (рис. 2). Відтак, у 2018 році загальний імпорт товарів перевищував експорт на 9801,1 млн дол. США (у 2017 році на 6342,5 млн дол. США), в той час як експорт аграрної продукції у 2018 році перевищував іiі імпорт на 13556,4 млн дол. США (у 2017 році на 13459,0 млн дол. США). За оперативними даними Державної служби статистики України за 9 місяців 2019 року негативне зовнішньоторговельне сальдо становило 7098,7 млн дол. США, тоді як аграрний сектор України має позитивне торговельне сальдо у 11730,0 млн дол. США [5]. Позитивна динаміка випереджання загального експорту над імпортом негативно впливає на розвиток та конкурентоспроможність вітчизняного ринку й на сальдо зовнішнього балансу. Незначні темпи й обсяги розвитку експортно-імпортних 
операцій в АПК свідчать про недосконалість розв'язання проблем адаптації зовнішньоекономічної діяльності до умов світового ринку [13]. Це дає підстави стверджувати, що стимулювання розвитку та забезпечення ефективності зовнішньоторговельної діяльності аграрних підприємств $€$ стратегічним завданням держави і $€$ повністю обгрунтованим як з огляду на наявний потенціал, так і на можливості його реалізації.

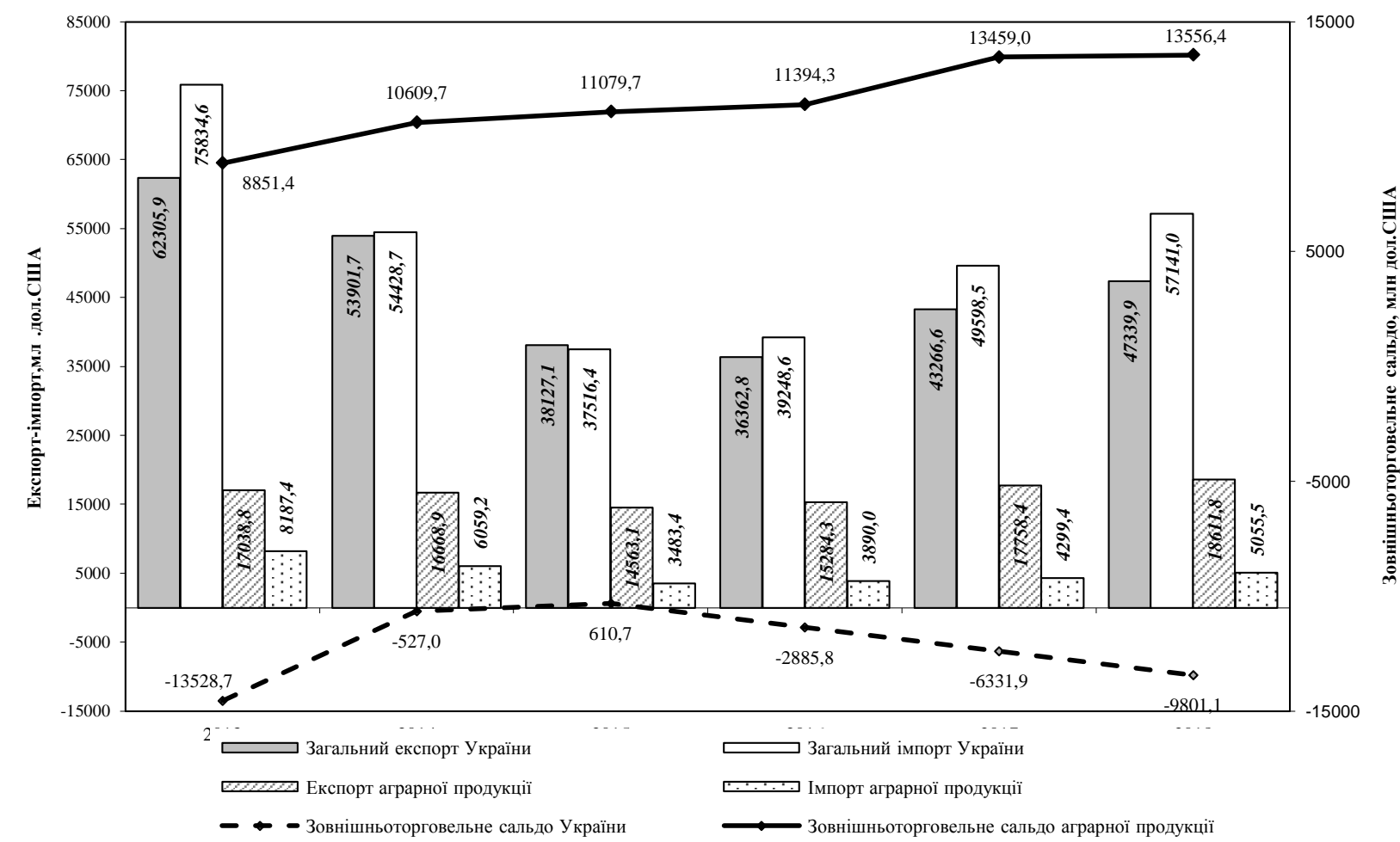

Рис. 2. Динаміка зовнішньої торгівлі України у 2013-2018 pp.

Джерело: сформовано автором на основі даних Державної служби статистики України [5]

Україна займає провідні позиції на світовій арені 3 експорту сільськогосподарської продукції, зокрема зернових культур, частка експорту яких у 2018 році становила 15,3\%, а за 9 місяців 2019 року - 18,4\% від загального обсягу експорту України. Загалом, частка експорту продукції рослинного походження у 2018 році становила 20,9\% від загального обсягу експорту України, жирів та олії тваринного або рослинного походження $-9,5 \%$, живих тварин та продукції тваринного походження - 2,6\% (табл. 1). Таким чином, експорт сировинної продукції аграрного сектора становить $33 \%$ від загального обсягу експорту України, тоді як частка експорту готових харчових продуктів лише $6,4 \%$, серед яких переважають залишки та відходи харчової промисловості (2,6\% від загального обсягу експорту України). Причому, подібна структура протягом останніх років відносно стабільна. Це свідчить про сировинну а্ орієнтацію аграрного виробництва України та переважання експорту вітчизняної продукції з низькою доданою вартістю, що зменшує можливості додаткових надходжень до держбюджету та гальмує зростання ВВП. 
EФМ

http://efm.vsau.org/

Таблиия 1

\section{Структура аграрного експорту у загальному обсязі експорту України у} 2010-2019 роках ${ }^{1}$

\begin{tabular}{|c|c|c|c|c|c|c|c|c|c|c|c|}
\hline \multirow[b]{2}{*}{ Назва товарів } & \multicolumn{10}{|c|}{ у \% до загального обсягу експорту України } & \multirow{2}{*}{$\begin{array}{c}+/- \\
2018 \\
\text { до } \\
2010\end{array}$} \\
\hline & $\stackrel{\circ}{\circ}$ & $\overline{\overbrace{}}$ & $\stackrel{\text { ก }}{\frac{1}{3}}$ & $\stackrel{m}{\stackrel{2}{2}}$ & $\frac{\text { i }}{8}$ & $\stackrel{n}{\stackrel{4}{s}}$ & $\frac{0}{\circ}$ & 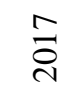 & $\stackrel{\infty}{\check{i}}$ & $\begin{array}{l}9 \text { мiс. } \\
2019\end{array}$ & \\
\hline $\begin{array}{lcc}\text { Живі тварини } & \text { та } & \text { продукти } \\
\text { тваринного походження: } & \end{array}$ & 1,5 & 1,4 & 1,4 & 1,7 & 1,9 & 2,2 & 2,1 & 2,6 & 2,6 & 2,6 & 1,1 \\
\hline - живі тварини & 0 & 0 & 0 & 0 & 0 & 0,1 & 0,1 & 0,1 & 0,1 & 0,1 & 0,1 \\
\hline - м’ясо та їстівні субпродукти & 0,2 & 0,3 & 0,5 & 0,6 & 0,7 & 1 & 1,1 & 1,2 & 1,4 & 1,4 & 1,2 \\
\hline - риба і ракоподібні & 0 & 0 & 0 & 0 & 0,1 & 0 & 0 & 0,1 & 0,1 & 0,1 & 0,1 \\
\hline $\begin{array}{l}\text { - молоко та молочні продукти, яйця } \\
\text { птиці; натуральний мед }\end{array}$ & 1,3 & 1,0 & 0,9 & 1,1 & 1,1 & 1,0 & 0,9 & 1,1 & 1,0 & 0,9 & $-0,3$ \\
\hline Продукти рослинного походження: & 7,8 & 8,2 & 13,5 & 14,2 & $\begin{array}{c}16, \\
2\end{array}$ & $\begin{array}{c}20, \\
9\end{array}$ & $\begin{array}{c}22, \\
3\end{array}$ & 21,3 & 20,9 & 24,3 & 13,1 \\
\hline - овочі & 0,2 & 0,2 & 0,2 & 0,2 & 0,2 & 0,3 & 0,4 & 0,5 & 0,5 & 0,4 & 0,3 \\
\hline - їстівні плоди та горіхи & 0,4 & 0,3 & 0,3 & 0,2 & 0,3 & 0,4 & 0,4 & 0,5 & 0,5 & 0,5 & 0,1 \\
\hline - зернові культури & 4,8 & 5,3 & 10,3 & 10,2 & $\begin{array}{c}12, \\
1\end{array}$ & $\begin{array}{c}15, \\
9\end{array}$ & $\begin{array}{c}16, \\
7 \\
\end{array}$ & 15,0 & 15,3 & 18,4 & 10,5 \\
\hline $\begin{array}{c}\text { - продукція } \\
\text { круп'яної промисловошнсі }\end{array}$ & 0,2 & 0,2 & 0,2 & 0,2 & 0,2 & 0,3 & 0,4 & 0,4 & 0,4 & 0,4 & 0,2 \\
\hline - насіння і плоди олійних рослин & 2,1 & 2,1 & 2,6 & 3,3 & 3,1 & 3,9 & 4,2 & 4,8 & 4,1 & 4,5 & 2,0 \\
\hline $\begin{array}{l}\text { Жири та олії тваринного або } \\
\text { рослинного походження }\end{array}$ & 5,1 & 5,0 & 6,2 & 5,6 & 7,1 & 8,7 & $\begin{array}{c}10, \\
9\end{array}$ & 10,6 & 9,5 & 9 & 4,4 \\
\hline Готові харчові продукти: & 5,0 & 4,3 & 5,1 & 5,6 & 5,7 & 6,5 & 6,7 & 6,5 & 6,4 & 6,3 & 1,4 \\
\hline - продукти з м’яса, риби & 0,1 & 0,1 & 0,1 & 0,1 & 0,1 & 0 & 0 & 0 & 0 & 0 & $-0,1$ \\
\hline $\begin{array}{l}\text { - цукор i кондитерські вироби } 3 \\
\text { цукру }\end{array}$ & 0,4 & 0,4 & 0,5 & 0,4 & 0,3 & 0,4 & 1,0 & 1,0 & 0,8 & 0,5 & 0,4 \\
\hline - какао та продукти з нього & 1,2 & 1,0 & 1,0 & 0,9 & 0,6 & 0,5 & 0,4 & 0,4 & 0,4 & 0,4 & $-0,8$ \\
\hline - готові продукти із зерна & 0,5 & 0,5 & 0,6 & 0,7 & 0,7 & 0,7 & 0,6 & 0,7 & 0,6 & 0,5 & 0,1 \\
\hline - продукти переробки овочів & 0,4 & 0,3 & 0,5 & 0,6 & 0,6 & 0,5 & 0,4 & 0,4 & 0,4 & 0,4 & 0,0 \\
\hline - різні харчові продукти & 0,2 & 0,2 & 0,3 & 0,4 & 0,4 & 0,3 & 0,3 & 0,3 & 0,3 & 0,3 & 0,1 \\
\hline $\begin{array}{l}\text { - алкогольні і безалкогольні напої та } \\
\text { оцет }\end{array}$ & 0,8 & 0,5 & 0,5 & 0,6 & 0,5 & 0,5 & 0,5 & 0,5 & 0,5 & 0,4 & $-0,3$ \\
\hline $\begin{array}{c}\text { - залишки і відходи } \\
\text { промисловості }\end{array}$ & 0,9 & 0,9 & 1,3 & 1,5 & 2,1 & 2,6 & 2,7 & 2,4 & 2,6 & 2,9 & 1,7 \\
\hline $\begin{array}{l}\text { - тютюн i промислові замінники } \\
\text { тютюну }\end{array}$ & 0,4 & 0,3 & 0,4 & 0,5 & 0,6 & 0,9 & $\begin{array}{l}0 \\
9\end{array}$ & 0,8 & 0,8 & 0,8 & 0,4 \\
\hline
\end{tabular}

${ }^{1}$ Без урахування тимчасово окупованої території Автономної Республіки Крим м. Севастополь та частини тимчасово окупованих територій у Донецькій та Луганській областях.

Джерело: сформовано автором на основі даних Державної служби статистики Украӥни [5]

Сировинна спрямованість українського експорту, серед інших причин, пов'язана 3 обмеженими можливостями вітчизняних агровиробників щодо закупівлі сучасного обладнання та устаткування внаслідок низької платоспроможності й технологічної відсталості. Суттєві витрати на дотримання стандартів СС скорочують можливості залучення до експортних поставок у Свросоюз вітчизняного малого i середнього бізнесу, адже впровадження технологічних інновацій, які б забезпечували виробництво продукції за європейськими стандартами, вимагає значних фінансових коштів на закупівлю 
обладнання, нематеріальних активів та перекваліфікації персоналу [11]. Загалом, сировинна орієнтація українського експорту робить конкурентні позиції України на зовнішніх ринках вразливими, оскільки попит на сировинні товари $\epsilon$ непостійним і характеризується значною ціновою мінливістю. Тому необхідно забезпечувати збільшення експорту готової продукції. Фактором нарощування аграрного експорту з високим рівнем доданої вартості, зокрема до $€ C$, $\epsilon$ підвищення вимог безпечності та якості харчових продуктів і сировини за рахунок впровадження на підприємствах систем управління якістю та систем управління безпечністю харчових продуктів [1]. В аграрній сфері торговельноекономічні відносини України та ЄС є певною мірою ускладненими через застосування високих тарифів та інших нетарифних інструментів [13], тому зниження торговельних бар'єрів та розвито зони вільної торгівлі може посилити конкурсні переваги України на європейському ринку аграрної продукції.

Асортимент аграрної продукції (табл. 1) свідчить про значні можливості цієї галузі. Майже за всіма найменуваннями спостерігається зростання експорту протягом 2010-2018 років, зокрема: частка експорту м'яса та їстівних субпродуктів збільшилась у 6,8 раз, зернових культур - в 3,2 рази, овочів - у 2,5 разів, тютюну - 2,1 рази, насіння і плодів олійних культур - у 2 рази. Одним із чинників відповідного розширення зовнішньоекономічної діяльності підприємств є географічна диверсифікація.

Нині країни ЄС залишаються найбільшими торговельними партнерами України. Питома вага цих країн у зовнішньоторговельному обігу товарів і послуг України за підсумками 2018 року становила 41,1\%, а частка експорту українських товарів до Європи становила 42,6\% від загального експорту. Протягом минулого року експорт товарів до країн $\mathrm{CC}$ зріс на $15,0 \%$ ङ (+2,6 млрд дол. США) і становив 20,2 млрд дол. США. Найбільше української продукції в Європі купують у Польщі, Італії, Німеччині. Не зважаючи на торговельні обмеження та значне скорочення експортно-імпортних операцій, Російська Федерація все ще залишалася серед основних торговельних партнерів України (у 2018 році 7,7\% українського товарного експорту було спрямовано до Росії та 14,1\% загального імпорту товарів до України становила російська продукція). Питома вага РФ у зовнішньоторговельному обігу товарів і послуг України за підсумками 2018 р. становила 12,9\%.

Негативний вплив на експорт України спричинило обмеження транзитного руху вантажів через територію Росії до третіх країн: Казахстану та Киргизії, що призвело до скорочення експортних поставок українських товарів не лише до країн Центральної Азії та Закавказзя, а й до інших країн Азії. Донині експортні втрати вітчизняної економіки лише частково компенсуються переорієнтацією на ринки інших країн [7].

Значними поціновувачами української продукції $є$ також Туреччина, ふ্ Китай, Індія, Сгипет. У 2018 році частка експорту вітчизняної продукції до цих країн становила відповідно $5 \%, 4,6 \%, 4,6 \%, 3,3 \%$. Причому, зовнішньоторговельний обіг товарів і послуг з Туреччиною за 2018 р. збільшився 
на $7,7 \%$ (+332,9 млн дол. США) i становив 4,6 млрд дол. США. Зовнішньоторговельний оборот товарів і послуг з Китаєм за 2018 р. збільшився на 27,3\% (+2,2 млрд дол.) та склав 10,1 млрд дол. США [3].

Особливістю сучасних зовнішньоторговельних угод України, в тому числі й в агропромисловому комплексі, $є$ їхній коротко- і середньостроковий характер. Проте, досвід високорозвинених країн засвідчує, що для завоювання сталих ніш на світовому ринку доцільно забезпечити тривалі міжнародні зв'язки. При здійсненні зовнішньої торгівлі важливе значення відіграють угоди щодо зон вільної торгівлі, укладання яких передбачає створення більш сприятливих умов для зовнішнього торговельно-економічного співробітництва 3 певними країнами або групами країн і $є$ достатньо дієвим та ефективним інструментом збільшення обсягів експорту через спрощення процедури доступу товарів чи послуг на іноземні ринки. Запровадження режиму вільної торгівлі 3 перспективними торговельно-економічними партнерами дає змогу Україні розширювати - географію та збільшувати товарний асортимент вітчизняного експорту.

При виході на зовнішній ринок, підприємства натрапляють на нові вимоги до своєї діяльності, котрі змушують їх удосконалювати технічні параметри виробництва, підвищувати продуктивність праці та якість продукції. Інтеграція України у світовий економічний простір, характерною особливістю якого $є$ високий рівень конкуренції, зумовлює необхідність переходу від екстенсивної моделі вітчизняної економіки до інноваційної моделі розвитку господарювання [10]. Держпродспоживслужба зазначає, що нині право експорту своєї продукції на територію Свросоюзу мають лише 308 українських підприємств, серед яких 128 підприємств-виробників продукції для споживання людиною, зокрема: 22 виробники молока та молочної продукції; 4 виробники м'яса птиці; 1 виробник продуктів із м'яса птиці; 24 виробники риби; 4 виробники яєць та яєчної продукції; 66 виробників меду; 1 виробник харчового колагену; 1 виробник кишкової сировини; 5 виробників равликів та жаб'ячих лапок, що є доволі мало відносно загальної кількості підприємств АПК України. Для спрямування експорту до ЄС український виробник має обов'язково проходити оцінку системи державного контролю (з подальшою верифікацією) та отримувати дозволи на експорт.

Аналізуючи виробничий та експортний потенціал аграрних підприємств України, можемо виділити їхні сильні та слабкі сторони (табл. 2).

Отже, основною проблемою для забезпечення подальшого розвитку зовнішньоекономічної діяльності аграрних підприємств $є$ невідповідна якість, i, як насідок, недостатня конкурентоспроможність їхньої продукції на зовнішньому ринку, зміцненню якої перешкоджає низка ендогенних та екзогенних чинників: низький рівень кредитування та державного фінансування аграрної галузі; нерозвиненість сфери аграрного страхування; недосконалість інфраструктури аграрних ринків; недотримання переважною більшістю вітчизняних підприємств міжнародних стандартів виробництва аграрної продукції; недостатня кваліфікація зайнятих в аграрному виробництві 
працівників; низька ефективність функціонування аграрної галузі порівняно 3 розвинутими країнами; невідповідність структури українського експорту попиту інших країн на продукцію агропромислового комплексу; неефективна державна політика протекціонізму; нестабільна економічна та політична ситуація в країні; низька інвестиційна привабливість $[1,8,9]$. Розв'язання перерахованих проблем сприятиме підвищенню конкурентоспроможності вітчизняної аграрної продукції як на внутрішньому, так і на зовнішньому ринку, додатковому залученню іноземних інвестицій та розвитку зовнішньоекономічної діяльності підприємств АПК.

Таблиия 2

\section{SWOT-аналіз аграрних підприсмств України}

\begin{tabular}{|c|c|}
\hline Сильні сторони & Слабкі сторони \\
\hline $\begin{array}{l}\text { 1. Сприятливі грунтово-кліматичні умови. } \\
\text { 2. Вирощування високоякісних сортів. } \\
\text { 3. Вигідне географічне розташування. } \\
\text { 4. Широкий асортимент продукції. } \\
\text { 5. Сприятливий мікроклімат підприємств. } \\
\text { 6. Виробничий потенціал розвитку аграрної галузі. } \\
\text { 7. Підписання митних та торгівельних угод. } \\
\text { 8. Інтеграція у європейській простір }\end{array}$ & $\begin{array}{l}\text { 1. Сировинна орієнтація. } \\
\text { Недостатній досвід у здійсненні ЗЕД. } \\
\text { 2. Слабка матеріально-технічна база. } \\
\text { 3. Невідповідність світовим стандартам якості та } \\
\text { безпечності харчових продуктів. } \\
\text { 4. Не налагоджена маркетингова, збутова та цінова } \\
\text { політика. } \\
\text { 5. Відсутність підтримки з боку держави. } \\
\text { 6. Недостатньо кваліфіковані працівники. } \\
\text { 7. Неоперативність митного оформлення товарів. }\end{array}$ \\
\hline Можливості & Загрози \\
\hline $\begin{array}{l}\text { 1. Виробництво екологічно-чистої продукції. } \\
\text { 2. Збільшення доходів підприємств. } \\
\text { 3. Залучення іноземних інвесторів. } \\
\text { 4. Украплення існуючих та захоплення нових } \\
\text { ринкових ніш. } \\
\text { 5. Отримання досвіду у здійсненні ЗЕД. } \\
\text { 6. Товарна та географічна диверсифікація ринків } \\
\text { збуту. } \\
\text { 7. Підписання вигідних зовнішньоторговельних угод. } \\
\text { 8. Пошук іноземних партнерів. } \\
\text { 9. Модернізація матеріально-технічної бази, } \\
\text { інноваційний розвиток. }\end{array}$ & $\begin{array}{l}\text { 1.Висока міжнародна конкуренція. } \\
\text { 2.Витіснення із ринкової ніші. } \\
\text { 3.Втрата позицій на внутрішньому та зовнішньому } \\
\text { ринках. } \\
\text { 4.Зменшення ціни на зернову продукцію. } \\
\text { 5.Втрата якості продукції при довготривалому } \\
\text { транспортуванні. } \\
\text { 6.Неефективні канали реалізації. }\end{array}$ \\
\hline
\end{tabular}

\section{Джерело: сформовано автором}

Обов'язковою умовою успішного розвитку зовнішньоекономічної діяльності підприємства $\epsilon$ розробка відповідної стратегії, яка $є$ сукупністю перспективних планів i завдань, які необхідно виконати, аби досягти поставлених цілей, а також правил і прийомів поведінки на зовнішньому ринку. Формуючи стратегію розвитку своєї зовнішньоекономічної діяльності, аграрні підприємства мають враховувати сучасні тенденції розвитку світового продовольчого ринку, зокрема: зміна структури споживання і зростання вимог до якості продуктів харчування в розвинутих країнах, збільшення обсягів міжнародної торгівлі екологічними товарами; зміна інституційної та організаційної структури світового ринку; випереджувальне зростання : міжнародної торгівлі готовими до вживання харчовими продуктами відносно сировинних; зростання масштабів міжнародної торгівлі генномодифікованими продуктами тощо. На думку експертів, такі тенденції будуть зберігатися на 
світовому продовольчому ринку ще наступні кілька десятиріч. За таких умов та враховуючи зростання впливу глобалізації на економіку України, рівень конкурентоспроможності вітчизняної аграрної продукції на світовому ринку безпосередньо залежатиме від того, наскільки адекватно вище перераховані тенденції будуть відображені в стратегіях підприємств, 3 одного боку, та адаптації системи державної політики i регулювання у сфері зовнішньоекономічної діяльності, з іншого.

Висновки. Для України, 3 iї потужним ресурсно-виробничим та експортним агропромисловим потенціалом, сприятливими природнокліматичними умовами, значними площами сільськогосподарських земель із високою родючістю, вигідним географічним розташуванням, розвинутою транспортною мережею та іншими сприятливими чинниками, зовнішньоекономічна діяльність на світовому ринку аграрної продукції може стати основою для подолання економічної кризи і пришвидшення економічного -

Можливими шляхами підвищення конкурентоспроможності продукції українських аграрних підприємств на міжнародному ринку є: забезпечення відповідності вітчизняних стандартів на продукцію агропромислового комплексу вимогам стандартів Свропейського Союзу; збільшення експортного потенціалу вітчизняних підприємств шляхом сприяння і впровадження систем управління якістю; налагодження співпраці підприємств агропромислового комплексу 3 науко-дослідними установами для покращення інноваційної складової виробництва; сприяння держави технічному i технологічному переоснащенню потужностей для виробництва експортної продукції; державна підтримка сільгоспвиробників у вигляді дотацій, податкових пільг, безпроцентних кредитів, у тому числі на купівлю землі для сільськогосподарського виробництва, що сприятиме укріпленню фінансовоекономічної стабільності вітчизняних виробників, мінімізації собівартості та ціни аграрної продукції; формування сприятливих умов для залучення іноземних інвестицій у аграрну сферу, в тому числі шляхом створення вільних економічних зон, технопарків та інших трансферних фірм; налагодження сучасної інфраструктури аграрного ринку та зовнішньоекономічної діяльності підприємств; покращення репутації України на міжнародному ринку як виробника екологічно чистої і безпечної продукції; закріплення позицій на наявних та освоєння нових закордонних ринків збуту; створення системи аналізу, прогнозування та стратегічного планування зовнішньоекономічної активності підприємств АПК; поліпшення кадрової складової експортноорієнтованих виробництв аграрної продукції тощо.

Системна підтримка вітчизняних експортно зорієнтованих аграрних українських підприємств повинна стати невід'ємною частиною єдиної збалансованої мережі інституцій із регулювання та підтримки міжнародної торгівлі. Для поліпшення інституційної здатності держави важливо забезпечити кваліфікований супровід зовнішньоекономічної діяльності вітчизняних 
підприємств із метою задоволення їхніх організаційних, інформаційних, дорадчих та агрологістичних потреб.

Своєчасну адаптацію до мінливих умов функціонування на міжнародному ринку аграрне підприємство здатне забезпечити за рахунок стратегічного управління розвитком зовнішньоекономічної діяльності, яке базується на оцінці тенденцій нестабільності зовнішнього середовища, оперативному реагуванні та упередженні зовнішніх загроз.

Подальші дослідження варто спрямувати на визначення ключових елементів ефективної стратегії стабільного економічного зростання аграрної галузі та поглиблення іiі інтеграції у світову економічну систему.

\section{Список використаних джерел}

1. Безп'ята I. Зовнішньоекономічна діяльність аграрного сектора джерело надходження іноземних інвестицій. Економічний дискурс. 2016. Вип. 3. ิે C. $16-25$.

2. Брояка А.А. Адаптація зовнішньоторговельної діяльності аграрних підприємств до сучасних економічних умов. Економіка, фінанси, право. 2016. № 4/2. C. $14-20$.

3. Зовнішня торгівля України товарами та послугами за 2018 рік. Офіційний веб-сайт Міністерства економічного розвитку і торгівлі України. URL: http://www.me.gov.ua/?lang=uk-UA (дата звернення: 20.03.2020)

4. Мельник Л.Г. Економіка та інформація: Економіка інформації та інформаційна в економіці: енциклопедичний словник. Суми: ВТД «Університетська книга», 2015. 384 с.

5. Офіційний сайт Державної служби статистики України. URL: Режим доступу: http://www.ukrstat.gov.ua/ (дата звернення: 20.03.2020)

6. Пахуча Е.В., Філімонов Ю.Л., Лещенко Л.О. Структурні зміни зовнішньої торгівлі України аграрною продукцією. Ефективна економіка. 2019. № 3. URL: http://www.economy.nayka.com.ua/?op=1\&z=6962 (дата звернення: 20.03.2020)

7. Пітель Н.Я. Проблеми розвитку експортоорієнтованої діяльності аграрної сфери економіки України. Агросвіт. 2019. № 16. С. 25-34.

8. Прощаликіна А.М., Петренко Т.С. Місце України на світовому ринку продукції АПК. Агросвіт. 2018. № 11. С. 22-26.

9. Сиротюк А.М. Особливості здійснення зовнішньоекономічної діяльності в агропромисловому комплексі. Наукові праці Полтавськоі державної аграрної академії. Серія: Економічні науки. 2013. Вип. 1 (6). Том 2. C. 279-283.

10. Ставська Ю.В. Управління конкурентоспроможністю підприємств суб'єктів зовнішньоекономічної діяльності. Стратегія розвитку України: ঞぇ фінансово-економічний та гуманітарний аспекти: матеріали VI Міжнародної науково-практичної конференції (м. Київ, 16 жовтня 2019 р.). Київ: «Інформаційно-аналітичне агентство», 2019. С. 329-332. 
11. Ставська Ю.В., Глуха А.О. Перспективи розвитку зовнішньоекономічної діяльності України в умовах євроінтеграції. Приазовський економічний вісник. 2018. Вип. 5(10). С. 59-64.

12. Хаєцька О.П. Перспективи розвитку зовнішньоекономічної діяльності агропромислових ринків. Міжрегіональна взаємодія логістичних систем в умовах трансформації економіки: матеріали міжнар. наук.-практ. конф., (м. Умань, 18-19 трав. 2018 р.). Умань: «Візаві», 2018. С. 118-121.

13. Хаєцька О.П. Сучасні тенденції зовнішньоекономічної діяльності України. Економіка. Фінанси. Право. 2017. № 2/2. С.79-83.

\section{References}

1. Bezpyata, I. (2016) Zovnishnoekonomichna diialnist ahrarnoho sektora dzherelo nadkhodzhennia inozemnykh investytsii [Foreign trade of the agricultural sector - the source of foreign investment]. Ekonomichnyi dyskurs - The economic discourse. Issue 3. pp. 6-25 [in Ukrainian].

2. Broyaka, A.A. (2016) Adaptatsiia zovnishnotorhovelnoi diialnosti ฐิ ahrarnykh pidpryiemstv do suchasnykh ekonomichnykh umov [Adaptation of agricultural enterprises foreign trade activity to the current economic conditions]. Ekonomika. Finansy. Pravo. - Economics. Finances. Law. \# 4/2. pp. 14-20 [in Ukrainian].

3. Zovnishnia torhivlia Ukrainy tovaramy ta posluhamy za 2018 rik [Foreign trade of Ukraine with goods and services for 2018] (2019) The official site of Ministry of Economic Development and Trade of Ukraine. Retrieved from http://www.me.gov.ua/?lang=uk-UA (data zvernennia: 20.02.2020) [in Ukrainian].

4. Melnyk, L.H. (2015) Ekonomika ta informatsiia: Ekonomika informatsii ta informatsiina v ekonomitsi: entsyklopedychnyi slovnyk [Economics and Information: Economics of Information and Information in Economics: An Encyclopedic Dictionary]. Sumy: VTD «Universytetska knyha», 384 p. [in Ukrainian].

5. Derzhavna sluzhba statystyky Ukrayiny [Official site of the State Statistics Service of Ukraine]. Retrieved from http://www.ukrstat.gov.ua/ (data zvernennia: 20.02.2020) [in Ukrainian].

6. Pakhucha, E.V., Filimonov, Yu.L. and Leshchenko, L.O. (2019) Strukturni zminy zovnishnoi torhivli Ukrainy ahrarnoiu produktsiieiu [Structural changes in Ukraine's foreign trade in agricultural products]. Efektyvna ekonomika. Vol. 3. Retrieved from: http://www.economy.nayka.com.ua/?op=1\&z=6962 (data zvernennia: 20.02.2020) [in Ukrainian].

7. Pitel, N.Ya. (2019) Problemy rozvytku eksportooriientovanoi diialnosti ahrarnoi sfery ekonomiky Ukrainy [Problems of the development of the exportoriented activity of the ukrainian agrarian economy] Agrosvit. Vol. 16. pp. 25-34 [in Ukrainian].

8. Proshchalykina, A.M. and Petrenko, T.S. (2018) Mistse Ukrainy na svitovomu rynku produktsii APK [Ukraine's place in the world market of agricultural products]. Agrosvit. Vol. 11. pp. 22-26 [in Ukrainian]. 
9. Syrotiuk, A.M. (2013) Osoblyvosti zdiisnennia zovnishnoekonomichnoi diialnosti v ahropromyslovomu kompleksi. Naukovi pratsi Poltavskoi derzhavnoi ahrarnoi akademii. Seriia: Ekonomichni nauky - Scientific works of Poltava State Agrarian Academy. Series: Economic Sciences. Vol. 1 (6). Part 2. pp. 279-283 [in Ukrainian].

10. Stavska, Yu.V. (2019) Upravlinnia konkurentospromozhnistiu pidpryiemstv - subiektiv zovnishnoekonomichnoi diialnosti. [Competitiveness management of enterprises - subjects of foreign economic activity] Stratehiia rozvytku Ukrainy: finansovo-ekonomichnyi ta humanitarnyi aspekty: materialy VI Mizhnarodnoi naukovo-praktychnoi konferentsii (Kyiv, 16/10/2019). Kyiv: «Informatsiino-analitychne ahentstvo». pp. 329-332 [in Ukrainian].

11. Stavska, Yu.V. and Hlukha, A.O. (2018) Perspektyvy rozvytku zovnishnoekonomichnoi diialnosti Ukrainy v umovakh Yevrointehratsii [Perspectives for the development of foreign economic activities of Ukraine in the conditions of European integration] Pryazovskyi economic herald. Vol. 5(10). pp. 59-64 [in Ukrainian].

12. Khaietska, O.P. (2018) Perspektyvy rozvytku zovnishnoekonomichnoi diialnosti ahropromyslovykh rynkiv. [Prospects for development of foreign economic activity of agro-industrial markets] Mizhrehionalna vzaiemodiia lohistychnykh system $v$ umovakh transformatsii ekonomiky: materialy mizhnar. nauk.-prakt. konf. (Uman, 18-19/05/2018). Uman: «Vizavi». pp. 118-121 [in Ukrainian].

13. Khaietska, O.P. (2017) Suchasni tendentsii zovnishnoekonomichnoi diialnosti Ukrainy [Morden tendencies of foring economic activity of Ukraine] Ekonomika. Finansy. Pravo. - Economics. Finances. Law. № 2/2. 79-83. [in Ukrainian].

\section{Відомості про автора}

БРОЯКА Антоніна Анатоліївна - кандидат економічних наук, доцент кафедри економіки, Вінницький національний аграрний університет (21008, м. Вінниця, вул. Сонячна, 3, e-mail: broyaka@vsau.vin.ua).

BROYAKA Antonina - Candidate of Economic Sciences, Associate Professor of the Department of Economics, Vinnytsia National Agrarian University (3 Soniachna St., Vinnytsia, 21008; e-mail: broyaka@vsau.vin.ua).

БРОЯКА Антонина Анатольевна - кандидат экономических наук, доцент кафедры экономики, Винницкий национальный аграрный университет (21008, г. Винница, ул. Солнечная, 3, e-mail: broyaka@vsau.vin.ua). 